\title{
Some observations on the physiology of Penicillium roqueforti Thom and Penicillium cyclopium Westling
}

\author{
D Vivier 1, M Rivemale 2, JP Reverbel 2, \\ R Ratomahenina ${ }^{1^{*}}, \mathrm{P}$ Galzy 1 \\ 1 Chaire de Microbiologie Industrielle et de Génétique des Microorganismes, \\ INRA-ENSA, 2, Place Viala, 34060 Montpellier Cedex; \\ ${ }^{2}$ Laboratoires de la Société des Caves de Roquefort, 12250 Roquefort-sur-Soulzon, France
}

(Received 21 November 1991; accepted 3 February 1992)

\begin{abstract}
Summary $-P$ roqueforti and $P$ cyclopium behave similarly towards different physiological parameters. $P$ cyclopium grows better between $10-20^{\circ} \mathrm{C}$, resists $\mathrm{NaCl}$ better and grows faster with lactose. Acetic acid and to a certain extent lactic acid inhibits the growth of the Penicillium at a clearly lower $\mathrm{pH}$ than internal cellular $\mathrm{pH}$.
\end{abstract}

Penicillium roqueforti/ Penicillium cyclopium / physiology / organic acid

Résumé - Remarque sur la physiologie de Penicillium roqueforti Thom et de Penicillium cyclopium Westling. $\mathrm{P}$ roqueforti et $\mathrm{P}$ cyclopium contaminant des pâtes persillées réagissent de façon assez voisine aux diverses variations des paramètres physicochimiques du fromage. Cependant, $\mathrm{P}$ cyclopium se développe mieux entre 10 et $20^{\circ} \mathrm{C}$, résiste mieux au sel et a une croissance plus importante sur lactose. L'acide acétique et, à un degré moindre, l'acide lactique, sont inhibiteurs lorsque le $\mathrm{pH}$ du milieu extracellulaire est inférieur au $\mathrm{pH}$ du milieu intracellulaire par suite d'une accumulation de l'acide dans le mycélium. Au contraire, ces acides peuvent être utilisés comme substrat lorsque le $\mathrm{pH}$ du milieu extérieur est $\geq \mathrm{pH}$ du milieu intérieur. II semblerait que ces acides traversent la membrane cellulaire sous forme non ionisée $\mathrm{RCOOH}$.

Penicillium roqueforti / Penicillium cyclopium / physiologie / acide organique

\footnotetext{
* Correspondence and reprints
} 


\section{INTRODUCTION}

Moulds are not usually present on the surface of blue-veined cheese. Sometimes cheeses may be contaminated by $P$ cyclopium growing on the 2 sides and the edge of the loaves during the first ripening phase (usually around the 13th and the 16 th day). This contamination is undesirable for technological reasons, ie allergy in the dairy staff; worse sticking of tinfoil during the "plombage" phase (start of the anaerobic phase); deterioration of organoleptic properties (Veau et al, 1981). This kind of contamination is a risk throughout the manufacturing process but its appearance is more frequent during the winter months. Our aim was to prevent this contaminant proliferation by studying some physiological characters of Penicillium.

\section{MATERIALS AND METHODS}

\section{Biological material}

Four strains were used for this study, two of which were industrial: Penicillium roqueforti (called RS in the text); and Penicillium cyclopium (called CS in the text).

The 2 other strains were provided by the Mycothèque de l'Université Catholique de Louvain (MUCL): Penicillium roqueforti Thom MUCL 29 151 (called RC in the text); Penicillium cyclopium Westling MUCL 14445 (called CC in the text).

Penicillium cyclopium corresponds to the species named Penicillium verrucosum Dierckx var cyclopium (Westling) Samson, Stolk et Hadlok, also identified as Penicillium aurantiogriseum Dierckx.

\section{Culture conditions}

Lodder's medium (yeast extract $3 \mathrm{~g} /$, peptone 5 $\mathrm{g} / \mathrm{l}$, glucose $10 \mathrm{~g} / \mathrm{l}$ ) was used for cultures in liquid medium. Media were sterilized by autoclav- ing at $120^{\circ} \mathrm{C}$ for $20 \mathrm{~min}$. Cultures were grown in Erlenmeyers flasks $(500 \mathrm{ml})$ filled to $1 / 10$ th of their volume and shaken (amplitude: $7 \mathrm{~cm}$; oscillations $80 / \mathrm{min}$ ) at $30^{\circ} \mathrm{C}$ for 5 days.

Czapek medium was used for solid media: $\mathrm{NaNO}_{3}(3 \mathrm{~g}), \mathrm{K}_{2} \mathrm{HPO}_{4}(1 \mathrm{~g}), \mathrm{MgSO}_{4}, 7 \mathrm{H}_{2} \mathrm{O}(0.5$ g), $\mathrm{KCl}(0.5 \mathrm{~g}), \mathrm{FeSO}_{4}, 7 \mathrm{H}_{2} \mathrm{O}(0.01 \mathrm{~g})$, sucrose $(30 \mathrm{~g})$, Agar $(20 \mathrm{~g}), \mathrm{pH}=6.5$. On modified media sucrose was substituted by an organic acid by maintaining the same amount of carbon per liter of medium.

\section{Analytical techniques}

\section{Determination of dry weight}

Mycelia were harvested by filtration (Millipore membrane $5 \mu \mathrm{m}$ ). Dry weight was determined by weighing the used filter until a constant weight after dessication at $105^{\circ} \mathrm{C}$.

\section{Measure of linear growth}

Growth was estimated by measuring the 2 perpendicular diameters of the thallus. These measurements were performed on the 2 largest colonies.

\section{pH determination}

External $\mathrm{pH}$ was determined with a $\mathrm{pH}$-meter. Internal $\mathrm{pH}$ was estimated by Kotyk's equation.

\section{RESULTS AND DISCUSSION}

\section{Influence of various physicochemical parameters on growth}

All growth determinations were carried out on Lodder's medium for the 4 strains.

\section{Temperature}

Figure 1 shows that the 4 microorganisms grew between $10-30{ }^{\circ} \mathrm{C}$; the optimal tem- 


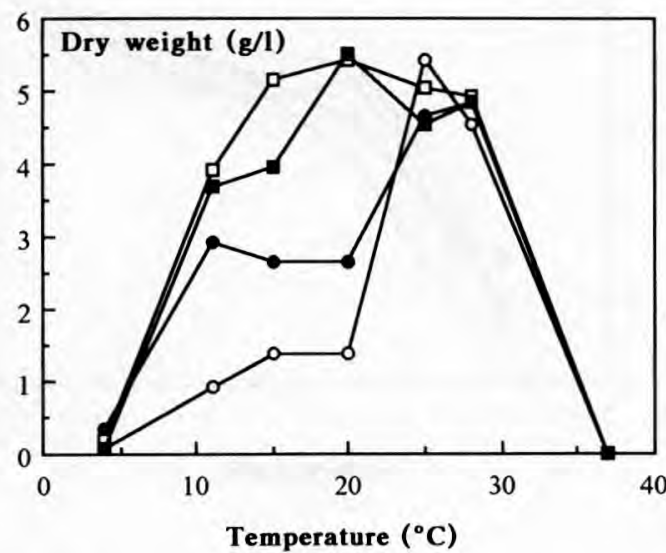

Fig 1. Estimation of Penicillium growth as a function of temperature. $-\mathrm{O}-P$ roqueforti $\mathrm{S}$; $\longrightarrow$ - $P$ roqueforti $\mathrm{C} ;-\square-P$ cyclopium $\mathrm{S}$; $\longrightarrow$ - $P$ cyclopium C.

Évaluation de la croissance de Penicillium en fonction de la température.

peratures for growth were $20^{\circ} \mathrm{C}$ for $P$ cyclopium and $25^{\circ} \mathrm{C}$ for $P$ roqueforti. However, $P$ cyclopium grew better between 10$20^{\circ} \mathrm{C}$.

\section{$\mathrm{pH}$}

For this study, media were buffered with tartrate or phosphate buffer. pH did not significantly influence growth. The 4 strains grew correctly between $\mathrm{pH} 3$ and $\mathrm{pH} 7$ with an optimum between $\mathrm{pH} 4$ and $\mathrm{pH} 5$.

\section{Salt content}

As indicated in figure 2, sodium chloride had a different action on growth in both species. When sodium chloride content was $5 \%(\mathrm{w} / \mathrm{v})$ only $P$ cyclopium (CS and CC) was able to grow significantly. With

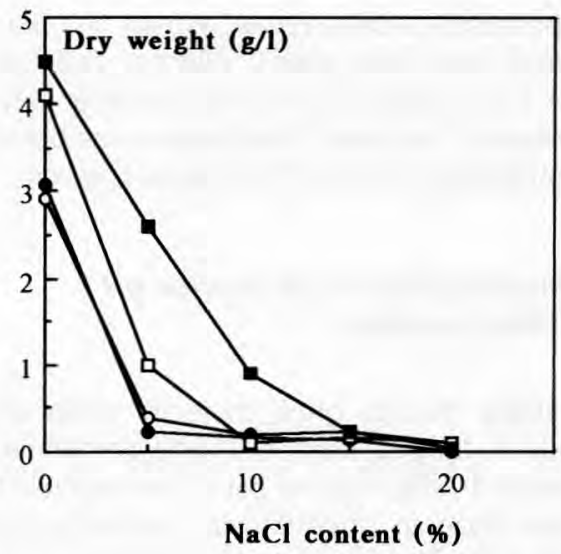

Fig 2. Estimation of Penicillium growth as a function of $\mathrm{NaCl}$ content. $-\mathrm{O}-P$ roqueforti $\mathrm{S}$;

$-\longrightarrow P$ roqueforti $\mathrm{C} ;-\square-P$ cyclopium $\mathrm{S}$; $-P$ cyclopium $\mathrm{C}$.

Évaluation de la croissance de Penicillium en fonction de la teneur en $\mathrm{NaCl}$.

$10 \%(w / v)$ only $P$ cyclopium (CC) grew. With $15 \%(w / v)$ sodium chloride, growth was completely inhibited.

The liquid medium probably modified the abilities of the strains to resist $\mathrm{NaCl}$. Indeed, $P$ roqueforti filled in a homogeneous manner the cheeseholes where $\mathrm{NaCl}$ content in water ranged from $10-20 \%$. Nevertheless, it seemed that $P$ cyclopium was more resistant than $P$ roqueforti to high $\mathrm{NaCl}$ contents.

\section{Osmotic pressure}

The influence of osmotic pressure was studied with various concentrations of glucose. No significant difference appeared between the 2 species; growth was optimal with $20 \%$ glucose. No mould developed at $60 \%$. 


\section{Carbon substrate}

The basal medium (yeast extract and peptone) gave weak growth. Glucose was better than lactose as a carbon source. Nevertheless, we noted that lactose was better metabolized by the $P$ cyclopium species.

\section{Determination of the internal $\mathrm{pH}$ of the mycelium}

Usually moulds grew correctly when $\mathrm{pH}$ values ranged from 4-7 and sometimes below 4 . The internal $\mathrm{pH}$ of the mycelium was close to physiological neutrality $(\mathrm{pH}$ 6.5-7.5). The internal pH of the 4 strains was estimated after growth on Lodder buffered medium over a wide range of $\mathrm{pH}$. Cells were centrifuged, washed and resuspended in bidistilled water, and crushed mechanically; dry weight was about 250 $\mathrm{mg} / \mathrm{ml}$. Direct measurement of $\mathrm{pH}$, with an electrode plunged in the crushed mycelium solution, allowed estimation of the internal $\mathrm{pH}$ values of the mycelium (fig $3 \mathrm{~A}$ ).

The internal $\mathrm{pH}$ was near physiological neutrality when the $\mathrm{pH}$ of the culture medium was above 4.5 . When the external $\mathrm{pH}$ was lower than 4.5 , the internal $\mathrm{pH}$ decreased.

Kotyk (1963) proposed an original method to estimate the internal $\mathrm{pH}$. According to MacMillan (1956), some uncharged molecules freely cross the plasmatic membrane of cells. So we can assume for instance, bromophenol blue $\left(p K_{\mathrm{a}}=4.0\right)$ enters the cells in its unionized forms. Equilibrium is reached. It allows an equal $\mathrm{RCOOH}$ concentration on both sides of the plasmatic membrane. Kotyk's equation, ie:

$p H i=p H o$

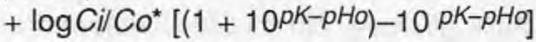
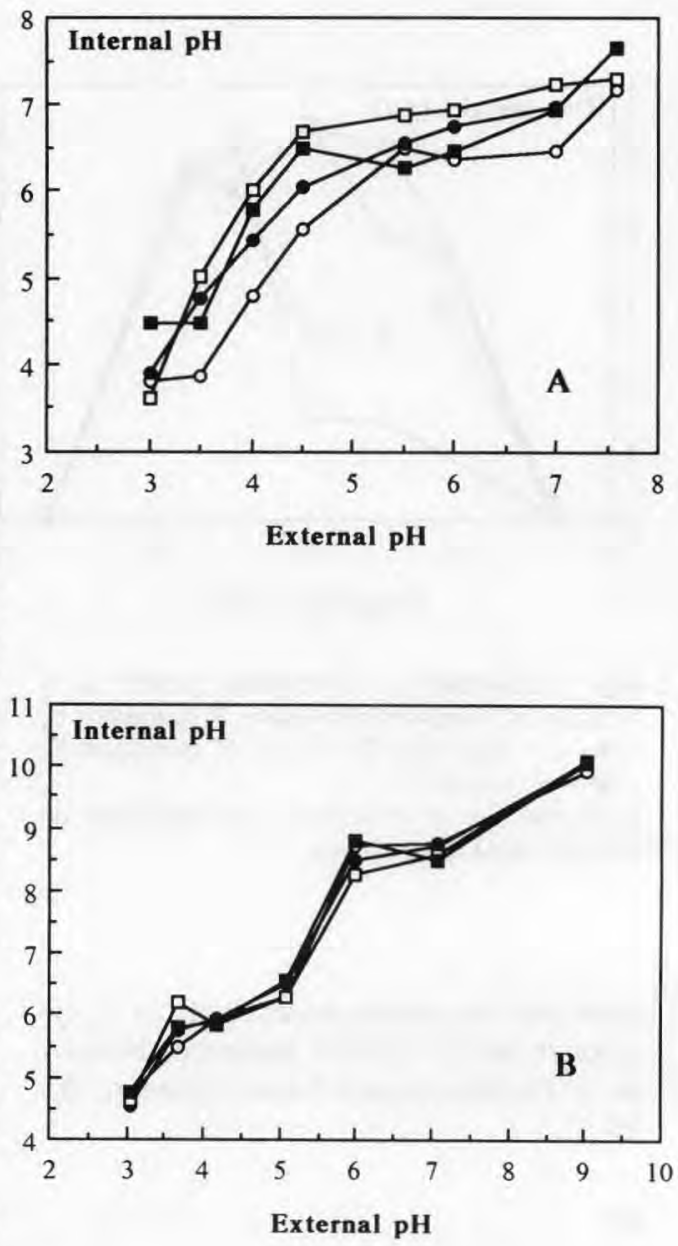

Fig 3. Estimation of internal $\mathrm{pH}$. $\mathrm{A}$ : $\mathrm{pH}$-metry determination. B: Determination by calculation. $-\mathrm{O}-\mathrm{P}$ roqueforti $\mathrm{S}$; $-\longrightarrow \mathrm{P}$ roqueforti $\mathrm{C}$; $\rightarrow-P$ cyclopium $\mathrm{S} ;-\rightarrow-P$ cyclopium $\mathrm{C}$. Évaluation du $\mathrm{pH}$ interne. $A$ : Détermination par pHmétrie. B : Détermination par le calcul.
$\mathrm{Ci}=$ intracellular concentration;
Co = extracellular concentration;
$\mathrm{pHi}=$ intracellular $\mathrm{pH}$; 
$p H o=$ media $\mathrm{pH}$;

$p K=p K$ of acid function

correctly describes this equilibrium.

So it is possible to estimate the internal $\mathrm{pH}$ of the mycelium (fig $3 \mathrm{~B}$ ) by studying the intracellular and exocellular concentration of bromophenol blue for various $\mathrm{pH}$ values of the medium. The internal $\mathrm{pH}$ of the mycelium was $\approx 6$ when the $\mathrm{pH}$ of the medium ranged from 3.5 to 5 . This $\mathrm{pH}$ zone, similar to the $p K$ value of bromophenol blue, provides, a priori, reliable results. So, it can be assumed that the internal $\mathrm{pH}$ of mycelium was about 6 . The 4 strains behaved similarly.

\section{Growth studies on various organic acids}

\section{Acetic and lactic acids}

The 4 strains were incubated in Lodder liquid media. Glucose, acetic acid or glucose and acetic acid mixture (1:1) were used as carbon sources. These different media were buffered from 3 to 8 .

Figure 4 clearly indicates that Penicillium strains grew well on glucose at all the tested $\mathrm{pH}$. The optimal $\mathrm{pH}$ for growth seemed close to 4 . On the contrary, growth with acetic acid as carbon substrate was really significant only at $\mathrm{pH} 7$ and 8 .

This can easily be explained if we consider that the Penicillium behave exactly in the same manner as Saccharomyces cerevisiae towards acetic acid. Conway and Downey (1949) previously showed that acetic acid penetrated through the Saccharomyces cerevisiae's cell wall in its uncharged form $(\mathrm{RCOOH})$. The equilibrium which can be calculated from equation 1 allows it to be shown that acetic acid penetrates normally at $\mathrm{pH} 7$ or $\mathrm{pH} 8$ but accumulates at low $\mathrm{pH}$.

For $p H o=3, C i=92 \mathrm{Co}$ and $\mathrm{Ci}=910 \mathrm{Co}$ for $\mathrm{pHi}$ equal to 6 and 7 respectively.

For $p H o=5, \mathrm{Ci}=5 \mathrm{Co}$ and $\mathrm{Ci}=100 \mathrm{Co}$ for $\mathrm{pHi}$ equal to 6 and 7 respectively.

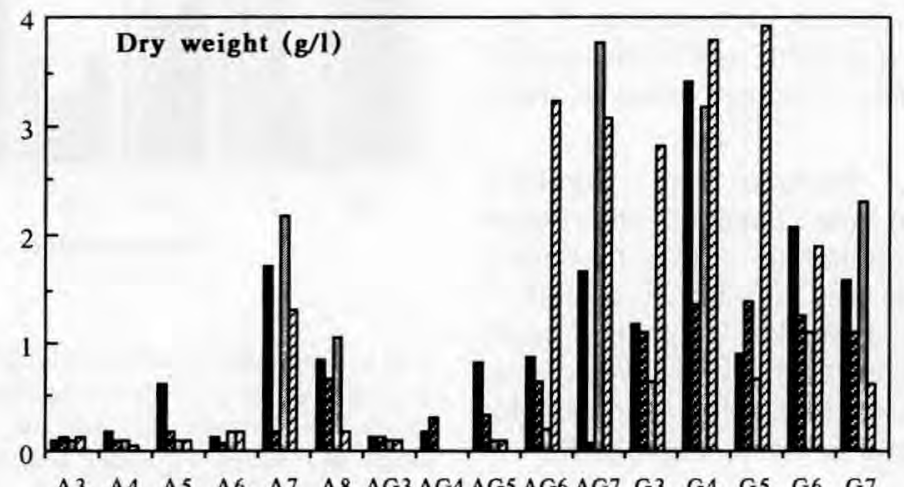

Carbon source

Fig 4. Estimation of Penicillium growth as a function of $\mathrm{pH}$ and carbon substrate. $P$ roqueforti $\mathrm{S}$; $\mathbb{P}$ roqueforti $\mathrm{C} ; \mathbb{Z} \mathrm{P}$ cyclopium $\mathrm{S} ; \mathbb{P}$ cyclopium $\mathrm{C}$. $\mathrm{A}=$ acetic acid; $\mathrm{G}$ : glucose; $\mathrm{AG}=$ acetic acid + glucose $3=\mathrm{pH} 3$.

Évaluation de la croissance de Penicillium en fonction $\mathrm{du} \mathrm{pH}$ et du substrat carboné. 
This hypothesis seems to be confirmed by the fact that acetic acid inhibits growth on glucose when external $\mathrm{pH}$ values are between 3 and 5 but stimulates it at $\mathrm{pH} 7$. Acetic acid probably penetrates into the mycelium in its uncharged form (RCOOH) with an accumulative effect when the exocellular $\mathrm{pH}$ is lower than the endocellular $\mathrm{pH}$.

On buffered Czapek solid medium, the 4 strains grew as well at $\mathrm{pH} 6$ as at $\mathrm{pH} 3$ when sucrose was used. On the same basal medium, the substitution of sucrose by lactic acid or acetic acid allows good growth at $\mathrm{pH} 6$. At pH 3, no mould developed on acetic acid but growth was significant on lactic acid (fig 5A). The addition of lactic or acetic acid weakly modified growth at $\mathrm{pH} 6$ but inhibited it at $\mathrm{pH} 3$ (fig $5 \mathrm{~B}$ ). Experiments $\mathrm{A}$ and $\mathrm{B}$ were independent.

These results confirm the toxic action of acetic acid when $\mathrm{pH}$ values are low. Lactic acid may have a less obvious but comparable action. That may be explained by the fact that the $p K$ value of lactic acid is clearly lower than that of acetic acid. Therefore, at the same $\mathrm{pH}$ the concentration of uncharged forms of lactic acid is less important than of the uncharged forms of acetic acid.

Moreover, Romano and Kornberg (1968, 1969) and Jennings and Austin (1973) showed that the utilization of many carbohydrates was inhibited by acetate in other species of moulds. Hunter and Segel (1973) also showed that many weak acids inhibited the organic solute transport for $\mathrm{pH}$ values equal or inferior to their $p K_{\mathrm{a}}$.

Nevertheless, our results are quite different from those previously described on Czapek medium. Veau et al (1981) showed that only $P$ cyclopium was able to grow on acetate at $\mathrm{pH} 6$. However, at this value of $\mathrm{pH}$, ie 6 , our strains of $P$ roqueforti were also able to grow.
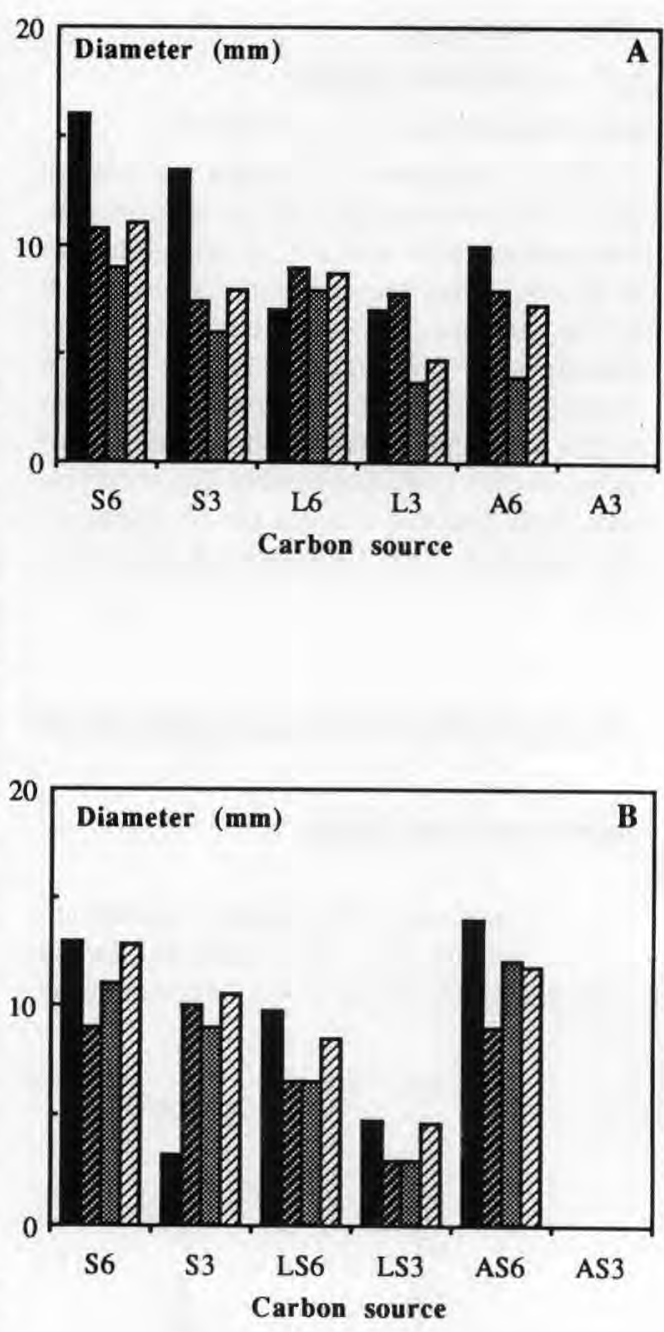

Fig 5. Estimation of Penicillium growth on Czapek media. A: Growth on sucrose or different acids. B: Growth on sucrose and different acids. $P$ roqueforti $S$; $P$ roqueforti $C$; $P$ Cyclopium $\mathrm{S}$; $P$ P cyclopium $\mathrm{C} . \mathrm{A}=$ acetic acid; $\mathrm{L}$ = lactic acid; $S=$ sucrose; $A S=$ acetic acid + sucrose; $\mathrm{LS}=$ lactic acid + sucrose $; 3=\mathrm{pH} 3 ; 6$ $=\mathrm{pH} 6$.

Evaluation de la croissance de Penicillium sur milieu de Czapek. A : Croissance sur saccharose ou acides organiques, B : Croissance sur saccharose et acides organiques. 
Engel and Teuber (1978) have observed that only $P$ roqueforti grew correctly on unbuffered $\mathrm{Czapek}$ liquid medium with sucrose in the presence of acetic or lactic acid. On all liquid media $P$ cyclopium strains grew well at $\mathrm{pH} 6$. As was previously shown on solid media, good growth at $\mathrm{pH} 6$ was observed in the presence of glucose and acetic acid, or acetic acid alone. But growth was inhibited by these organic acids for $\mathrm{pH}$ under 5 .

In fact, the results of Veau and Engel could be explained if the tested strains presented a barrier towards acetic acid or lactic acid. In this case, the organic acids cannot be used as carbon substrate at $\mathrm{pH} 7$. If this barrier exists, there will not be a toxic action for low $\mathrm{pH}$ caused by an accumulation process. The 2 strains we used did not present this characteristic. The observations we made for $P$ cyclopium are quite comparable to those described by the above-mentioned authors.

\section{Oleic acid}

The 4 strains were cultured in liquid and solid Czapek media. Oleic acid replaced sucrose as carbon source. These different media were buffered at $\mathrm{pH}$ 5-7.

The 4 strains grew well on all these media. However, growth of $P$ roqueforti was more significant than that of $P$ cyclopium.

This ability of $P$ cyclopium to metabolise fatty acids could play a part in the efficiency of the "morge". Indeed, fatty acids undoubtedly favour sticking of tin foil during the "plombage" phase and fatty acid metabolisation by $P$ cyclopium may explain decreased sticking of tin foil.

\section{CONCLUSIONS}

The results suggest that acetic and lactic acid penetrate into the mycelium in the 4 strains under their $\mathrm{RCOOH}$ form, as previously described by Conway and Downey (1949) for other moulds.

Consequently, these microorganisms are able to grow on these organic acids when exocellular $\mathrm{pH}$ is close to neutrality. The second consequence is the accumulation of these organic acids when media $\mathrm{pH}$ is lower than internal $\mathrm{pH}$; this induces an inhibition of mycelial growth. These observations are similar to those concerning $P$ cyclopium made by other authors. The behaviour of our $2 P$ roqueforti strains did not seem to be markedly different in our study.

Since the amount of salt added to the cheese during manufacture has decreased over recent years, sometimes there was an undesirable growth of mycelium ("boure") located only on the surface of some loaves. It appears that during the first ripening phase $P$ cyclopium grows better than $P$ roqueforti. This growth may be related to a better resistance to $\mathrm{NaCl}$, better growth at $9-12{ }^{\circ} \mathrm{C}$ and to a better metabolisation of the residual lactose for $P c y$ clopium strains.

\section{REFERENCES}

Conway EJ, Downey M $(1949) \mathrm{pH}$ values of the yeast cell. Biochem J 47, 355-360

Engel G, Teuber M (1978) Simple aid for the identification of Penicillium roqueforti Thom. Eur J Appl Microbiol Biotechnol 6, 107-111

Hunter DR, Segel IH (1973) Effects of weak acids on amino acid transport by Penicillium chrysogenum: evidence for a proton or charge gradient as the driving force. $J$ Bacteriol 113, 1184-1192

Jennings DH, Austin S (1973) The stimulatory effect of the non-metabolized sugar 3-0methylglucose on the conversion of mannitol and arabitol to polysaccharide and other insoluble compounds in the fungus Dendryphiella salina. J Gen Microbiol 75, 287-294 
Kotyk A (1963) Intracellular $\mathrm{pH}$ of baker's yeast. Folia Microbiol 8, 27-31

MacMillan (1956) The entry of ammonia into fungal cells. J Exp Bot 7, 113-126

Romano AH, Kornberg HL (1968) Regulation of sugar utilization by Aspergillus nidulans. Biochim Biophys Acta 158, 491-493
Romano AH, Kornberg HL (1969) Regulation of sugar uptake by Aspergillus nidulans. Proc $R$ Soc Lond Ser B 173, 475-490

Veau P, Samson RA, Breton A (1981) Étude comparée de Penicillium roqueforti et Penicillium verrucosum var cyclopium. Lait 61, 370380 